\section{Desalination Research}

IN reply to a question in the House of Lords on March 11 regarding progress in the problem of desalting water, Lord Snow said that the Water Research Association had made good progress in studying the economic factors underlying the provision of sweet water, and a mission was to leave shortly for the United States for discussions with the Office of Saline Water. The Committee on Desalination Research had considored a research programme in conjunction with industry, and the Atomic Energy Authority had undertaken work on the use of nuclear energy for a desalination plant. The Committee and the Authority had watched closely work in the United States and elsewhere. British industry had already established, primarily for arid areas, a commercially proved method for converting sea-water into fresh in the multi-stage flash evaporator which was regarded as the most efficient in use to-day. Over the past 10 years British firms had supplied some 40 installations to various parts of the world, representing more than 70 per cent of the land-based plants in operation. The Government recognized the need to support research to maintain Britain's lead in a potentially growing export market, and the Minister of Technology hoped to make a statement fairly soon on plans for increasing the scale of effort on desalination research. Lord Snow said he was aware of the design studies at the Oakridge National Laboratory of the Atomic Energy Commission in Tennessee for a desalting plant with a capacity of 20 million gallons a day, with a possible increase of up to $50-100$ million. gallons a day. Co-operation was continuing in basic research, but Britain's effort would have to be increased if she were to maintain her present strong position.

\section{British Space Research}

IN written answers in the House of Commons on March 5 , the Secretary of State for Education and Science, Mr. A. Crosland, stated that the 3 scientists and 4 engineers in the Space Research Management Unit of his Department were the only ones engaged on space research and directly responsible to him. They would be transferred to the Science Research Council when that Council was formed. The Convention establishing the European Space Research Organization came into operation in March, 1964, and a financial protocol provided for a programme of space research (with sounding rockets and satellites) over the 8 years up to 1972 . The programme for 1965 provided for launching 33 experiments in 14 payloads with sounding rockets. Contracts were being placed for 27 Centaure rockets from Sud Aviation de France and 20 Skylark rockets from the British Aircraft Corporation, and a contract for a satellite to investigate solar X-rays and cosmic radiation (to be launched in the spring of 1967) was being negotiated with Hawker-Siddeley Dynamics. Preliminary design studies had been completed for a polar ionospheric satellite to be launehed towards the end of 1967 and tenders for its development invited. A large satellite of stellar astronomy experiments was scheduled for launching in 1968-69 and preliminary proposals for payloads were being considered. The Organization had established. a space technology centre in the Netherlands and was establishing a space laboratory nearby. A data centre was being established in Germany and a launching range at Kiruna in Sweden. The Organization awarded fellowships to enable space scientists from member states to study in other member states or, under an agreement with the National Aeronautics and Space Administration, in the United States.

\section{Co-operation in Pharmacology between Milan and Buffalo}

Arrangements have been concluded for a close working relationship between the Institute of Pharmacology of the University of Milan (director, Prof. E. Trabucchi) and the Department of Biochemical Pharmacology of the State University of New York at Buffalo (chairman, Prof. J. F. Danielli). The arrangements were evolved after a visit by Prof. R. Paoletti to Buffalo, and a visit by Dean D. H. Murray of the School of Pharmacy at Buffalo, together with Prof. Danielli, to Milan. Collaboration between the Institute and the Department will involve exchange of staff, of research students and of technicians, the sharing of certain equipment, and the organization of a joint symposium annually. In 1965 the first symposium, on "Cell Permoability and Transport Phenomena", will be organized from Milan (secretary, Dr. L. Bolis, Via Alamanni, 19, Milan, Italy). The 1966 symposium will be held at Buffalo on "Drugs Affecting the Immune Response", and the 1967 symposium will be held at Milan on "Peptides".

\section{New Museum and Art Gallery, Doncaster}

H.R.H. Princess Margaret, Countess of Snowdon, accompanied by the Earl of Snowdon, officially opened the new Museum and A.rt Gallery, Doncaster, on October 30,1964 . The new building cost just more than $£ 291,000$ and replaces the old museum and art gallery, now demolished, which was housed in an eighteenth-century building for 55 years. The new building consists of a main exhibition block on two floors, the ground floor being Museum and the first floor Art Gallery, with a part used temporarily for costume and uniforms. About half the Art Gallery is air conditioned. Attached to the main block is a separate wing containing the administrative offices, laboratories, store-rooms and workshops.

\section{Western Australian Museum, Perth}

THE Western Australian Museum has received many objects from the wrecks of the Dutch East Indiamen of the seventeenth century, now lying on the sea-bed at no great distance from the shore. The Museum has been kept fully informed of this interesting work, but there is no existing legal provision which would enable the State to control the recovery of the material from these ships, which antedates Captain Cook by more than 100 years, and is thus of great interest in early Australian history. The objects already handed over to the State collection include an astrolabe, two apothecary's mortars, a protractor and a pair of navigator's dividers. The annual report of the Museum for 1963-64 includes a very useful list of type specimens in the zoological collections (Pp. 46. Perth: Western Australian Museum, 1964).

\section{The Museums Journal}

THE Museums Journal for December 1964 (3, No. 3) includes an interesting and useful paper on typography in museums, and emphasizes the importance of the visual impact made by a wise selection of printed display matter. The prehistoric collections at the National Museum in Prague are described especially from the point of view of modern display. The remainder of the issuo gives an account of the 1964 annual conference at Nottingham and includes a verbatim report of the presidential address by Dr. Dilwyn John. The Journal is produced in the attractive format which it has used during the past few years.

\section{Man}

The journal Man for November-December 1964 contains a number of important articles. On the social anthropological side there are papers on "Networks in Indian Social Structure", by Prof. M. N. Srinivas and André Béteille, and on "New Guinea Highland Models and Descent Theory", by Dr. R. F. Salisbury. Two accounts of iron smelting, one in north-east Nigeria and the other in Zambia not far from Livingstone, are also of special interest. In Nigeria the ore is magnetic iron ore, said by Przeworski not to be suitable for smelting, though David Livingstone described cases where it was 